\title{
The additional phrases on a Genizah fragment of Bavli Eruvin 4b-5a
}

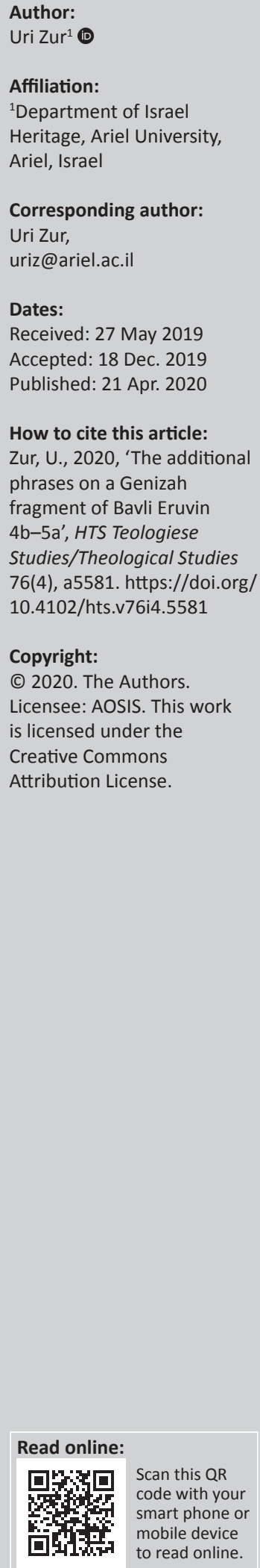

This article deals with the additional phrases found in the Cairo Genizah fragment related to Bavli, Tractate Eruvin 4b-5a, identified as Cambridge UL T-S F1 (1) 44. FGP No. C 96446. Some of these additional phrases have not been found in any version of the various manuscripts and printed versions, and some were found in only one version. The purpose of the article was to examine whether these additional phrases preserve an ancient version that was only preserved in this Genizah fragment or whether they are a type of errors in the fragment. The conclusions of the article with regard to these additional phrases are varied; some of the phrases preserve an ancient version and some do not.

Keywords: Genizah; Eruvin; sugya; phrases; kil ayim; interpolation; immersion.

\section{Description of the Genizah fragment}

The fragment is a segment from the Cairo Genizah, which refers to Tractate Eruvin in the Talmud Bavli (4b-5a), and it is identified as Cambridge UL T-S F1 (1) 44. Here, we shall refer to one folio from the fragment, numbered C96446, in the Friedberg Jewish Manuscript Society website and selected at random.

The length of the page is $27.4 \mathrm{~cm}$. There are 30 lines in each page. The length of the inscribed part is $21 \mathrm{~cm}$.

The folio is torn along the entire outer left edge and perforated at the bottom. The edges of the fragment are faded because of damp stains.

The fragment opens with the words 'די.....' (4b) and ends with the words 'דפ[ת][ וכי תימא' (5a).

From a palaeographic perspective, the type of writing in the fragment is of a familiar type, that of R. Joseph ben Jacob Rosh Hasseder (Ginat 1990) who lived in the late 12th century.

\section{The exposition of the fragment}

The fragment begins with the topic of interposition in ritual immersion, where strict observation of issues related to interposition depends on the individual strictness practiced by the bather and is determined at the exclusive discretion of the bather. This is also the halakha determined by R. Isaac (who used the term dvar torah, i.e. '[According to] traditional $\left.l \mathrm{w}^{\prime 1}\right)$, whereby if something interposes between a major part of the bather's body and the waters of the ritual bath (such as dry blood ${ }^{2}$ ), and he personally is strict about this, that is, it causes him sorrow ${ }^{3}$ (although most people are not strict about this and are not grieved by this) - then that interposition is considered an interposition for the bather. However, if the bather is not strict about this, even if the interposition covers a major part of his body - it is not considered an interposition for the bather rather, on the contrary, this interposition is considered an integral part of the bather's body. This law pertaining to personal strictness with regard to matters of interposition, which is at the discretion of the bather, is very ancient (Gilat 1968:235) (which also appears in the scrolls from Qumran) (Regev 1996:9-21; Reich 1997:127-128). 


\section{The word kil ayim and the phrase 'The cubits of kil 'ayim'}

The word 'כלאים' Kil'ayim (12) in the fragment appears to be a scribal error affected by the sugyot above, 'אמת כלאים באמה בת ששה' (the cubits [applicable to the laws] of kil'ayim is one of six 'רשב"ג אומר כל אמות שאמרו חכמים בכלאים באמה בת ששה'(handbreadths] (R. Simeon b. Gamaliel ruled: All cubits of which the sages spoke in relation to kil'ayim are of the standard of six [handbreadths]). ${ }^{5}$ According to R. Simeon b. Gamaliel, it seems that the cubits of kil'ayim cannot be of five handbreadths as in the fragment, as the cubits of kil'ayim should be stricter because the prohibition against sowing kil'ayim (e.g. sowing grain in a vineyard) is grave because of its biblical origins. ${ }^{6}$ Therefore, the cubits of kil'ayim are cubits of six handbreadths rather than five handbreadths, as mentioned in the fragment. This is evident from the very fact that the fragment has

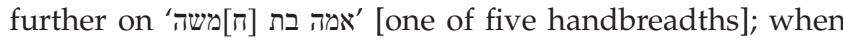
wherever an 'אמת כלים' [מת 'אמה ' [the cubits used for furniture] is mentioned, it is indeed of five handbreadths. ${ }^{7}$ (There is admittedly a dispute between R. Meir and R. Judah about the size of the cubits in the temple, whether six handbreadths or of five handbreadths ${ }^{8}$; however, even R. Meir admits that the size of the golden altar's cubits [Ginzberg 1969:17] was also measured with the cubits used for furniture, ${ }^{9}$ which were of five handbreadths ${ }^{10}$ ).

Hence, it can be concluded that 'אמת כלאים באמה בת [ח]משה טפחים (the cubits [applicable to the laws] of kil'ayim is one of six), mentioned in the fragment, is as stated a scribal error affected by the sugyot above, and therefore, all those versions that have 'אמת כלים באמה בת חמשה' [the cubits used for furniture were only one of five handbreadths] are correct, rather than the version of the fragment.

\section{The additional phrases in the Genizah fragment}

The additional phrases in the fragment which incorporate the words of R. Dimi (18-21) note the possibility that the dispute is between R. Joseph and Abaye concerning the words of R. Dimi ${ }^{11}$ (in the context of the tannaitic dispute) ${ }^{12}$ (Aminoah 2016:783-784, 921, 952-953); however, it must be stated that the additional phrases are a gloss that entered the fragment as an interpolation, because there is no other source that cites R. Dimi's words as a possible dispute between R. Joseph and Abaye in the sugya in Tractate Eruvin (5a).

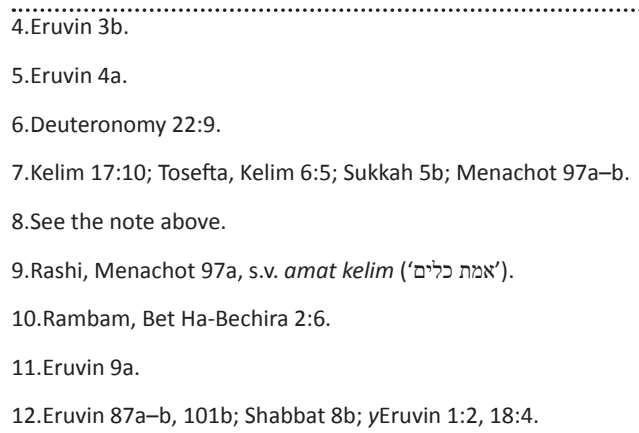

Another additional phrase is ניעבו נסיה בגיצא ואבע... ' (22). This phrase is unclear because of the fragmented words within it, and its contents are vague. Its lack of connection to the topic of the fragment and its absence from other manuscripts and printed versions raise the possibility that this phrase too is an additional phrase, a gloss that entered the fragment as an interpolation, similar to the previous phrase.

Then again, another additional phrase in the fragment is that of 'דאמר רב' [de-amar Rav] (29), which is missing from most of the manuscripts (except for MS Vatican 109) and from most of the printed versions. These manuscripts and printed versions have the term 'דתניא' (de-tanya) instead of the phrase ["אין מבוי ניתר בלחי וקורה"] דאמר רב" [the movement of objects in an alley cannot be permitted on the Sabbath by means of a side post and a cross-beam]. These alternative versions raise two questions. Firstly, how is it that in the fragment, the phrase 'אין מבוי ניתר בלחי וקורה' [the movement of objects in an alley cannot be permitted on the Sabbath by means of a side post and a cross-bea] (appears as a statement citing 'דאמר רב' [de-amar Rav], while in the rest of the manuscripts and printed versions, the phrase appears with a term for citing a baraita 'דתניא' [de-tanya]? Secondly, what is the correct version, the phrase 'דתניא' 'דאמר רב' [de-amar Rav] or the termya]?

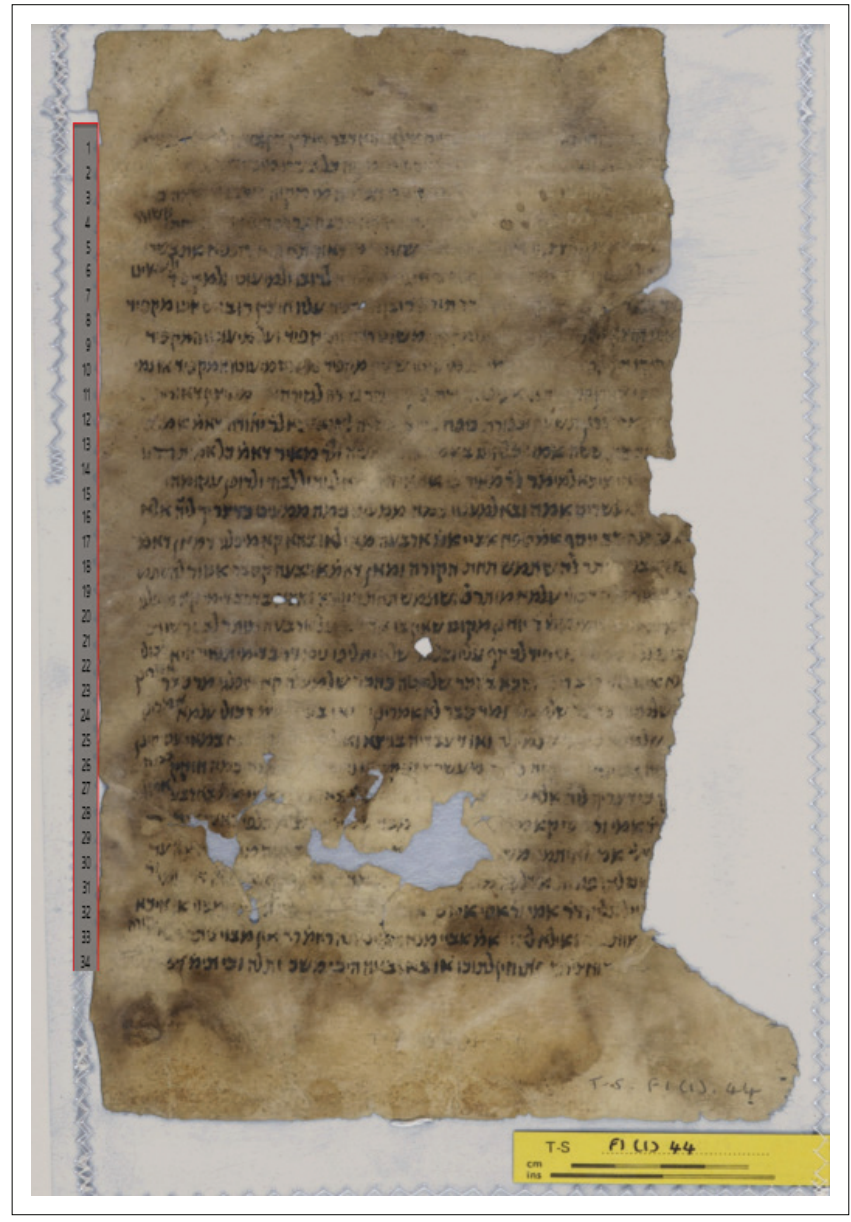

Source: The Friedberg Jewish Manuscript Society, n.d., The Syndics of Cambridge University Library, viewed n.d., from https://fjms.genizah.org/

FIGURE 1: Cambridge U-L T-S F1 (1) 44 
In reply to the first question, it must be stated that the Talmud Bavli indeed sometimes states a certain phrase in one place as a baraita, and in another - as a statement of the speaker, and this is a common phenomenon (Albeck 1969:234-235). Thus, the alternative versions, that of the fragment 'דאמר רב' [de-amar Rav] and that of the other manuscripts and printed versions 'דתניא' [de-tanya], are not surprising. In reply to the second question, the version of the fragment, which cites in the name of 'דאמר רב' [de-amar Rav], should be preferred over the term 'דתניא' [de-tanya] that appears in the other manuscripts and printed versions. Thus, as also in R. Hananel's commentary, he interprets the words of Abaye as based on those of 'Rav':

$[A]$ nd Abaye intended to clarify his words through the words of Rav who said that the movement of objects in an alley cannot be permitted on the Sabbath by means of a side-post and a cross-beam. ${ }^{13}$

and R. Hananel does not note 'דתניא' [de-tanya]. Moreover, some also define the phrase 'דאמר רב' 'דת' [de-amar Rav] as the 'true version' (Rabbinovicz 1960:7 n.100) and that which is correct, rather than 'דתניא' [de-tanya], because there are other references that state explicitly 'אמר רב אין מבוי ניתר בלחי וקורה' and do not have 'דתניא' [de-tanya]. Therefore, the fragment's version, with 'דאמר רב' 'דת' [de-amar Rav], is the correct version, rather than the version with 'דתניא' [de-tanya] as appears in the other manuscripts and printed versions.

\section{Conclusion}

There are several additional phrases in the Genizah fragment. The first additional phrase that incorporates the words of R. Dimi (19-22) is a gloss that entered the fragment as an interpolation, because no other source cites R. Dimi's words. The second additional phrase ' ואו ניעבדיה..(22) is unclear, and its contents are vague. Its lack of connection to the topic of the fragment and its absence from other manuscripts and printed versions raise the possibility that this phrase too is an additional phrase, a gloss that entered the fragment as an interpolation, similar to the previous phrase. However, the third additional phrase 'דאמר רב' [de-amar Rav] (29) is the correct version, rather than the version with 'דתניא' [de-tanya] as appears in the other manuscripts and printed versions.

\section{Acknowledgements}

The author thanks Dr Ezra Chwat for his assistance in describing the fragment, the Manuscripts Department and the Institute of Hebrew Manuscript Facsimiles at the National Library in Jerusalem, and the Syndics of Cambridge University Library for the permission to use the reproduction of Cambridge UL T-S F1 (1) 44.

\section{Competing interests}

The author has declared that no competing interest exist.

\section{Author(s) contributions}

All authors contributed equally to this work.

\section{Ethical consideration}

This article followed all ethical standards for a research without direct contact with human or animal subjects.

\section{Funding information}

This research received no specific grant from any funding agency in the public, commercial, or not-for-profit sectors.

\section{Data availability statement}

Data sharing is not applicable to this article as no new data were created or analysed in this study.

\section{Disclaimer}

The views and opinions expressed in this article are those of the authors and do not necessarily reflect the official policy or position of any affiliated agency of the authors.

\section{References}

Albeck, CH., 1969, Mechkarim ba-Baraita ve-Yachassan la-Talmud, pp. 234-235, Mossad Harav Kook, Jerusalem.

Aminoah, N., 2016, The redaction of the Shabbat and Eruvin tractates of the Babylonian Talmud, pp. 783-784, 921, 952-953, Tel Aviv University Press, Tel Aviv.

Gilat, Y.D., 1968, The teachings of R. Eliezer ben Hyrcanos and their position in the history of the Halakha, p. 235, Dvir, Jerusalem.

Ginat, L., 1990, 'R. Joseph Rosh Hasseder and his commentaries to the Mishnah (from the Geniza)', M.A. thesis, Tel Aviv University.

Ginzberg, L., 1969, Geonica, Genizah Studies II, p. 17, Makor, Jerusalem.

Rabbinovicz, R., 1960, Dikdukei Sofrim, Eruvin, p. 7 no.100, Ma'ayan ha-hokhma, Jerusalem. Regev, E., 1996, 'Ritual baths of Jewish groups and sects in the second Temple period', Cathedra 79, 9-21.

Reich, R., 1997, 'Miqwa'ot (ritual baths) at Qumran', Qadmoniot 30(2), 127-128.

The Friedberg Jewish Manuscript Society, n.d., The Syndics of Cambridge University Library, viewed n.d., from https://fjms.genizah.org/ 